\title{
Apakah yang dimaksud dengan proyek percontohan REDD+? Klasifikasi awal berdasarkan beberapa kegiatan awal di Indonesia
}

Erin Myers Madeira, Erin Sills, Maria Brockhaus, Louis Verchot dan Markku Kanninen

\section{Poin-poin utama}

- Infobrief ini memberikan gambaran awal tentang 17 proyek percontohan REDD+ yang dikembangkan di Indonesia pada pertengahan tahun 2009.

- Terdapat variasi yang tinggi dalam pelaksanaan dan uji coba proyek percontohan REDD+ yang dilakukan oleh para pemrakarsa.

- Tiga dimensi utama yang bermanfaat untuk mengelompokkan proyek-proyek percontohan tersebut adalah: 1) tingkat perencanaan tata ruang dan heterogenitas dari klasifikasi hutan, 2) strategi untuk menyelesaikan klaim jangka panjang terhadap karbon, dan 3) faktor pendorong dan penyebab utama deforestasi dan degradasi.

- Lazimnya, model konsesi dalam contoh proyek percontohan REDD+ ini dijelaskan berdasarkan kesesuaiannya dengan tata kawasan tenurial yang berlaku saat ini dan dengan prasyarat untuk menunjukkan kepemilikan karbon jangka panjang yang terjamin sebagai syarat untuk menjual kredit di pasar karbon sukarela.

- Proyek-proyek percontohan REDD+ yang menerapkan model konsesi berisiko meneruskan bias dan hambatan terhadap sistem konsesi yang ada saat ini, termasuk fokus pada hutan produksi dan kecenderungan untuk tidak melibatkan petani kecil dalam keputusan-keputusan tentang pengelolaan. Menanggapi adanya ketidaksetaraan dan ketidakefisienan dari tata kawasan tenurial yang berlaku saat ini membutuhkan reformasi kebijakan yang lebih luas dan tindakan berskala lebih besar daripada apa yang mungkin dapat dicapai oleh proyek percontohan individu.

- Tingginya biaya-biaya transaksi menghambat pengembangan proyek percontohan yang bermitra langsung dengan para petani kecil dalam mengurangi emisi. Berbagai model dan strategi baru harus dikembangkan untuk mengurangi biaya-biaya transaksi ini, contohnya dengan menyatukan atau menggabungkan inisiatifinisiatif kecil menjadi kegiatan yang lebih besar.

- Penelitian lebih lanjut diperlukan, baik untuk menilai dampak dari berbagai tipe proyek percontohan yang berbeda maupun untuk memperbaharui klasifikasi ini agar lebih dapat merefleksikan pesatnya pertambahan jumlah proyek percontohan REDD+ dan cepatnya perubahan kerangka kerja kelembagaan maupun peraturan untuk REDD+ di Indonesia. 


\section{Pendahuluan}

Pada tahun 2007, berbagai pihak dalam Konvensi Kerangka Kerja Perubahan Iklim PBB (UNFCCC) telah menyepakati Bali Roadmap, yang mendorong para pelaku di berbagai negara maju dan berkembang untuk segera melakukan mitigasi emisi karbon dari sektor kehutanan. Para pembuat kebijakan, investor, organisasi donor dan lembaga swadaya masyarakat (LSM) merespon inisiatif ini dengan memelopori berbagai kegiatan untuk mengurangi emisi dari deforestasi dan degradasi hutan dan mendorong adanya konservasi, pengelolaan hutan yang berkelanjutan, serta peningkatan cadangan karbon hutan di sejumlah negara berkembang (Keputusan UNFCCC 2/CP.13-11), yang lebih dikenal dengan sebutan 'REDD+'. Tanpa adanya sebuah kesepakatan dalam UNFCCC, akan muncul ketidakpastian mengenai apa saja yang akan tercakup dalam program REDD+ internasional. Meski dengan ketidakpastian yang ada, pengembangan berbagai kegiatan REDD+ terus berlanjut. Sebagai contoh, Wertz-Kanounnikoff dan Kongphan-Apirak (2009) mengidentifikasi adanya 109 kegiatan REDD+ di seluruh dunia: 44 proyek percontohan yang bertujuan langsung mengurangi emisi dari deforestasi dan degradasi, serta 65 kegiatan persiapan yang dirancang untuk menciptakan kerangka kerja pendukung bagi proyek REDD+ yang sebenarnya.

Dengan 56\% emisi yang bersumber dari deforestasi, degradasi dan konversi lahan gambut, serta komitmen untuk menurunkan emisinya sebanyak $41 \%$ pada tahun 2020 melalui 'cara yang biasa dilakukan' dengan kondisi adanya bantuan dari komunitas internasional (Boer dkk. 2010), Indonesia akan menjadi pemasok penting di berbagai skema REDD+ internasional manapun. Pemerintah Indonesia telah mendukung berbagai negosiasi internasional maupun bilateral tentang REDD+ dan telah proaktif di dalam negeri untuk membangun sebuah kerangka kerja peraturan untuk kegiatan REDD+ subnasional. Kegiatan-kegiatan utama yang telah dilakukan mencakup pembentukan Aliansi Iklim Hutan Indonesia atau Indonesian Forest Climate Alliance (IFCA) pada tahun 2007, dan pembentukan Dewan Nasional Perubahan Iklim (DNPI) yang bersifat lintas kementerian pada tahun 2008. Pada tahun 2009, Kementerian Kehutanan menetapkan prosedur untuk mengurangi emisi dari deforestasi dan degradasi hutan melalui Permenhut 30, Menhut II/2009, yang mendefinisikan peserta, tipe hutan, peran dari pemrakarsa proyek dan berbagai tingkatan pemerintah yang harus dipenuhi untuk sebuah kegiatan REDD+ (Atmadja dan Wollenberg 2010), dan untuk pemberian izin pemanfaatan komersial penyerapan dan penyimpanan karbon di dalam hutan produksi dan hutan lindung (Permenhut 36, Menhut II/2009). Pada bulan Mei 2010, pemerintah Indonesia dan
Norwegia menandatangani surat pernyataan kehendak atau Letter of Intent untuk bekerjasama dalam REDD+. Namun belum ada kejelasan mengenai bagaimana berbagai tindakan pengaturan akan diterapkan dan apakah langkah Kementerian Keuangan di masa mendatang akan mengalahkan aturan Kementerian Kehutanan yang berlaku saat ini. Meskipun pada kenyataannya masih ada kendala sistem peraturan yang rumit dan tidak jelasnya arsitektur kelembagaan nasional, para investor dan donor telah berinvestasi pada lebih dari 30 proyek percontohan REDD+.

Dalam infobrief ini, kami mengusulkan sebuah klasifikasi dari proyek percontohan REDD+ di Indonesia berdasarkan analisis struktur awal (yang berlaku pada pertengahan 2009) dari 17 proyek percontohan. Kami juga mendiskusikan beberapa kemungkinan penyebab mengapa tipe tertentu lebih banyak dilakukan daripada tipe yang lain. Klasifikasi ini dimaksudkan untuk memfasilitasi pemahaman, proses berbagi pembelajaran awal dan pembuatan rancangan penelitian proyek percontohan REDD+ di masa mendatang.

\section{Proyek-proyek percontohan REDD+ awal di Indonesia}

Kami mendefinisikan kegiatan percontohan' REDD+ sebagai kegiatan-kegiatan yang: 1) bertujuan secara langsung mengurangi emisi dari deforestasi dan degradasi pada kawasan-kawasan yang dapat dibedakan secara geografis dan saling berbatasan, yang 2) dapat dikenali oleh para pendukungnya sebagai REDD+, dan 3) beroperasi sesuai kesepakatan resmi dengan pemerintah di level tertentu. ${ }^{2}$

Hasil yang kami peroleh didasarkan pada penilaian terhadap proyek-proyek percontohan REDD+ di empat pulau (12 berlokasi di Kalimantan yang merupakan fokus dari penelitian ini, 2 berlokasi di Sumatra, 2 berlokasi di Papua dan 1 berlokasi di Sulawesi), yang dipilih secara strategis untuk mewakili tipe-tipe hutan utama, faktor pendorong deforestasinya dan tipe-tipe pendukung proyek yang terlibat dalam REDD+ di Indonesia. Sampai dengan pertengahan tahun 2009, masing-masing dari 17 proyek percontohan ini telah melewati fase konsep, namun masih dalam tahap perencanaan ataupun tahap awal implementasi. Berkebalikan dengan berbagai kegiatan percontohan yang tercantum dalam CIFOR (2010), contoh mencakup proporsi yang lebih besar dari berbagai kegiatan percontohan yang dikembangkan di Kalimantan dan Papua, serta sejumlah kegiatan percontohan yang beroperasi pada skala bentang alam sebagaimana dijelaskan di bawah ini. Contoh yang kami ambil mencakup tiga dari empat kegiatan percontohan REDD+ yang dikenal sebagai aktivitas percontohan atau 
demonstration activities (DA) oleh Pemerintah Indonesia sampai dengan bulan Februari 2010 (Pemerintah Indonesia 2010).

Penilaian kami terhadap berbagai kegiatan percontohan ini dilakukan berdasarkan tinjauan terhadap dokumen proyek, wawancara semi terstruktur dengan para pemrakarsa proyek, ${ }^{3}$ dan 21 wawancara terbuka dengan para rekanan proyek, pakar utama dan pemangku kepentingan, yang dilaksanakan oleh penulis pertama antara bulan Februari dan September 2009. Dengan demikian, awalnya kami mencoba memahami pandangan dan tujuan dari para pemrakarsa proyek, termasuk beragam koalisi dari LSM internasional, sejumlah investor domestik maupun asing, perusahaan swasta yang mengkhususkan diri pada pengembangan proyek REDD+, sejumlah agribisnis dan perusahaan kayu, Pemerintah Indonesia dan organisasi donor internasional yang bermitra dengan Pemerintah Indonesia. Untuk masing-masing kegiatan, kami mengumpulkan data tentang lokasi, luasan, klasifikasi legal atas hutan, tingkat perencanaan tata ruang, strategi untuk menetapkan klaim karbon jangka panjang, tipe-tipe ancaman (pemicu deforestasi dan degradasi), agen deforestasi ataupun degradasi, reaksi terhadap ancaman, kegiatan jangka pendek, kegiatan jangka panjang, standar yang digunakan, target pasar, manfaat tambahan, batas waktu dan tipe dari pemrakarsa proyek. Dari kesemuanya ini, sebanyak lima variabel digunakan untuk menetapkan klasifikasi yang diusulkan.

Sejumlah kegiatan percontohan REDD+ yang diteliti dalam penelitian ini direncanakan untuk mengimplementasikan serangkaian kegiatan, termasuk insentif positif, pertukaran lahan, wanatani, rehabilitasi atas hutan dan lahan gambut yang terdegradasi, bentuk praktik terbaik untuk operasi kayu dan hutan tanaman, serta berbagai elemen perencanaan tata ruang. Tiga belas dari 17 (76\%) kegiatan percontohan direncanakan untuk mencari validasi pihak ketiga dengan menggunakan Standar Karbon Sukarela atau Voluntary Carbon Standard (VCS) maupun standar Aliansi Komunitas Iklim dan Keanekaragaman Hayati atau Climate Community and Biodiversity Alliance (CCBA). Untuk dapat memperoleh validasi ini, beberapa kegiatan percontohan saat ini mengembangkan metodologi baru untuk deforestasi yang dihindari (VCS 2010) yang akan bergantung pada proses validasi ganda berdasarkan panduan VCS (wWw.V-C-s.org).

Karena besarnya ketidakpastian terkait sejumlah kegiatan spesifik dan sistem pembagian keuntungan yang akan diimplementasikan ke dalam kegiatan percontohan REDD+, kami memfokuskan pada keputusan struktur awal mereka tentang strategi dasar untuk mengurangi emisi karbon. Terdapat tingkat perbedaan dan pencobaan yang besar dalam struktur dari berbagai kegiatan percontohan tersebut. Kami mengidentifikasikan sejumlah dimensi penting di mana terdapat variasi dan selanjutnya membantu untuk mendefinisikan tipe-tipe kegiatan percontohan yang berbeda. Meskipun klasifikasi ini hanya didasarkan pada sejumlah fitur kegiatan percontohan yang telah ditentukan pada awal pengembangannya, keputusan struktural pendahuluan tersebut penting karena mereka membentuk jalur yang tersedia untuk implementasi. Hasilnya juga akan dipengaruhi oleh pengelolaan proyek dan keputusan-keputusan implementasi berikutnya, demikian pula kerangka kerja kelembagaan dan peraturan yang terus berubah di mana proyekproyek REDD+ dirancang, dikembangkan dan divalidasi. Namun demikian, kami yakin bahwa adanya keputusan struktural pendahuluan merupakan bagian yang sangat bermanfaat untuk mengenali kegiatan percontohan yang akan mempengaruhi alur implementasinya.

\section{Klasifikasi dari berbagai kegiatan percontohan REDD+}

\section{Tingkatan perencanaan tata ruang dan heterogenitas dalam klasifikasi hutan}

Berbagai kegiatan percontohan REDD+ dapat dikelompokkan menjadi tingkat lokal atau tingkat bentang alam, bergantung pada sampai sejauh mana mereka melibatkan perencanaan tata ruang dan apakah kegiatan percontohan tersebut mencakup areal hutan dengan beberapa klasifikasi yang berbeda menurut hukum. VCS menuntut agar semua tipe kegiatan percontohan harus memiliki perbatasan yang terdefinisi dengan jelas, agar dapat mengukur pengurangan dalam emisi dan pembuangan. Sejumlah kegiatan percontohan pada tingkat bentang alam bertujuan untuk mengurangi emisi bersih dari adanya keragaman bentang alam yang mencakup berbagai bentuk pemanfaatan lahan dan klasifikasi legal atas hutan. Mereka menggabungkan berbagai bentuk penggunaan lahan dan juga dapat melibatkan konsesi kayu ataupun pertambangan yang masih aktif. Kegiatan percontohan pada tingkat bentang alam ini secara aktif melibatkan proses perencanaan tata ruang, yang menuntut adanya kolaborasi dan dukungan dari pemerintah setempat dan provinsi yang bersangkutan, serta berbagai kementerian nasional Pemerintah Indonesia. Umumnya kegiatan percontohan tersebut mencakup areal yang besar di mana dijumpai berbagai pemicu deforestasi, dan umumnya mengambil beberapa langkah untuk mengurangi emisi dan meningkatkan pembuangan pada sublokasi yang lebih spesifik. Sebagai contoh, sebuah kegiatan percontohan pada tingkat bentang alam dapat terkait dengan 
proses perencanaan tata ruang pada suatu kecamatan untuk menjembatani perluasan perkebunan kelapa sawit dan perkebunan lain di atas lahan terdegradasi dan membatasi berbagai operasi yang secara intensif menghasilkan emisi pada hutan-hutan tua. Pada saat yang sama, mendorong praktik-praktik pengelolaan terbaik pada konsesi kayu dan secara langsung mendukung konservasi pada daerah-daerah yang bernilai tinggi. Dengan demikian, sebuah kegiatan percontohan pada tingkat bentang alam kemungkinan tidak hanya secara aktif mengelola keseluruhan wilayahnya untuk tujuan karbon saja.

Sebaliknya, kegiatan percontohan pada tingkat lokal hanya menargetkan suatu areal khusus di mana hutan memiliki klasifikasi legal yang homogen (misalnya: 'hutan produksi', 'hutan produksi konversi') atau, pada sedikit kasus, merupakan dua klasifikasi yang berhubungan erat. Keseluruhan areal hutan pada kegiatan percontohan tingkat lokal secara aktif dikelola untuk mengurangi emisi. Sebuah kegiatan percontohan tingkat lokal juga membutuhkan persetujuan dari pejabat Pemerintah Indonesia yang berwenang dan haruslah selaras dengan rencana tata ruang. Namun demikian, berbeda dengan kegiatan percontohan pada tingkat bentang alam, kegiatan percontohan pada tingkat lokal pada umumnya menggunakan rencana tata ruang sebagaimana adanya: sejumlah kegiatan tersebut merupakan bentuk manifestasi dari rencana tata ruang, dan tidak mempengaruhi rencana tersebut. Hal ini tidak berarti bahwa pemilik dan organisasi lain yang bekerja pada kegiatan percontohan tingkat lokal tidak bekerja sama dengan pemerintah; kenyataannya, mereka dapat secara aktif berusaha untuk membentuk peraturan setempat untuk kegiatan percontohan REDD+, termasuk rencana tata ruang. Namun demikian, hasil dari kerjasama politis ini tidak mempengaruhi dampak dari kegiatan percontohan dalam hal emisi karbon bersih.

\section{Strategi untuk menetapkan klaim atas karbon}

Untuk dapat menjual kredit karbon, seorang pemrakarsa proyek haruslah dapat menunjukkan suatu klaim yang berjangka panjang secara hukum. Sebagai contoh, VCS mensyaratkan agar pemrakarsa proyek harus memiliki tanda bukti hak yang menunjukkan 'hak mereka terhadap pengurangan emisi gas rumah kaca ... dan kepemilikan proyek' (VCS 2008a).

Di dalam konteks pengaturan di Indonesia yang kompleks dan terus berubah, sebagian besar pilihan untuk menetapkan klaim karbon ditentukan oleh sistem tenurial atas lahan hutan yang ada saat ini. Hampir seluruh hutan Indonesia dikelola oleh Pemerintah Indonesia di bawah undang-undang. Kurang dari 6\% dari hutan negara secara resmi ditentukan secara formal untuk dimanfaatkan oleh komunitas atau masyarakat pribumi atau dimiliki oleh perusahaan ataupun pribadi (Sunderlin dkk. 2008; Hinrichs dkk. 2008). Meskipun pembelian dan penjualan lahan hutan dilarang, terdapat sejumlah pilihan lain untuk memperoleh klaim secara hukum bagi sumber daya hutan - sebagai contoh, melalui konsesi kayu dan pertanian. Namun demikian 'hak karbon' tidak secara eksplisit dibahas di dalam peraturan yang ada saat ini, dan tidak terdapat jalur yang jelas yang dapat menunjukkan klaim legal secara khusus bagi karbon. Meskipun terdapat sejumlah ketidakjelasan ini, sejumlah pemrakarsa proyek telah berinvestasi di dalam pengembangan berbagai kegiatan percontohan REDD+, yang mencerminkan keyakinan mereka bahwa mereka akan dapat menetapkan suatu klaim berjangka panjang yang legal atas karbon. Untuk menetapkan klaim karbon berjangka panjang seperti itu, para pemrakarsa di Indonesia menggunakan salah satu dari empat strategi yang ada.

1. Model konsesi. Konsesi hutan merupakan hal yang umum dipraktikkan di hutan tropis untuk pemanenan hutan produksi maupun pengelolaan sumber daya hutan, dimana pada kedua kasus tersebut, terutama untuk kayu. Logika yang mendasari hal tersebut adalah 1) karena hutan menyediakan serangkaian barang dan jasa untuk umum, mereka harus tetap berada di bawah kepemilikan publik, namun 2) pemerintah tidak memiliki kapasitas, modal maupun pengalaman untuk mengelola dan memanen kayu secara efisien (Gray 2002). Namun demikian, sistem Hak Pengusahaan Hutan (HPH) di Indonesia telah lama menuai kritik karena alokasi kontrak yang tidak efisien, kegagalan untuk menangkap nilai tegakan batang kayu, dan tidak cukupnya pengamanan untuk manfaat nonkayu. Sejumlah kritik ini mempercepat terjadinya reformasi pada akhir 1990an, termasuk meningkatnya pajak, pembatasan pasar yang lebih sedikit dan proses desentralisasi untuk mengalokasikan konsesi kecil, yang diikuti oleh suatu pembalikan sebagian dari kebijakan tersebut pada pertengahan 2000an, yang disebabkan oleh berlanjutnya degradasi dan deforestasi dengan cepat (Barr dkk. 2006; Resosudarmo 2004). Di Indonesia, persediaan kayu juga bergantung pada sistem konsesi paralel untuk pembangunan hutan tanaman industri (HP-HTI), termasuk sejumlah izin berjangka pendek untuk menebang habis areal hutan yang ditetapkan sebagai hutan terdegradasi dan ditujukan untuk hutan tanaman (IPK).

Beberapa pemrakarsa di Indonesia memilih untuk mendapatkan hak konsesi atas daerah hutan yang tercakup dalam kegiatan percontohan mereka. Hal tersebut dapat berupa sebuah konsesi pemanenan kayu tradisional, di mana pihak pemrakarsa ataupun rekanan akan mempraktikkan pengelolaan hutan secara lebih 
lestari seperti halnya pembalakan berdampak rendah. Namun demikian, strategi yang lebih umum digunakan, yang diterapkan oleh tujuh dari delapan kegiatan percontohan dengan model konsesi, adalah untuk memperoleh Konsesi Restorasi Ekosistem atau Ecosystem Restoration Concession (ERC), yaitu sebuah konsesi bersifat khusus provinsial yang setara ERC untuk provinsi Papua. Kementerian Kehutanan telah menetapkan pilihan ERC untuk hutan produksi terdegradasi pada tahun 2007. Pemegang konsesi berkewajiban untuk melaksanakan berbagai kegiatan restorasi dan berhak untuk memperoleh penerimaan dari karbon dan berbagai bentuk pembayaran atas jasa lingkungan yang lain, dengan syarat memenuhi persyaratan perizinan yang sedang dikembangkan di bawah kerangka kerja pengaturan yang terus berkembang. ERC hanya dapat diperoleh bagi areal hutan yang diklasifikasikan sebagai hutan produksi dan hutan produksi-konversi, dan mensyaratkan adanya beberapa persetujuan dari otoritas kabupaten, provinsi dan nasional (misalnya untuk penilaian dampak terhadap lingkungan, dan konsultasi dengan pemangku kepentingan setempat). Provinsi Aceh dan Papua memiliki status otonomi khusus. Di Papua, beberapa pemrakarsa proyek bekerja dengan kantor gubernur untuk menyelidiki peluang apakah mereka dapat membentuk sebuah provinsi yang setara dengan ERC yang tidak mensyaratkan persetujuan dari sekian banyak tingkatan pemerintahan. Sistem ERC memungkinkan diselenggarakannya kepastian tenurial berjangka panjang (60+35 tahun). Hal tersebut nampaknya sangat menarik dalam konteks REDD+, meskipun dalam kenyataannya biaya transaksi untuk membentuk konsesi semacam itu sama dengan biaya transaksi untuk konsesi kayu dan konversi.

\section{Kemitraan dengan pemakai lahan. Seorang} pemrakarsa dapat saja membuat kesepakatan dengan pemakai lahan yang sudah ada untuk mengembangkan dan membagi kredit karbon dari sebuah kegiatan percontohan. Pengusul proyek tidak dapat memperoleh hak secara hukum terhadap wilayah maupun karbon, tetapi ikut ambil bagian dalam kontrak kesepakatan dengan pemilik lahan yang secara hukum berhak atas lahan dan oleh karena itu dianggap dapat memperoleh hak atas karbon. Pengusul proyek sepakat untuk mengembangkan kegiatan percontohan dan memperoleh bagian yang dihasilkan dari keuntungan karbon sebagai kompensasinya. Sebagai contoh, para pemakai lahan ini kemungkinan merupakan pemegang konsesi kayu yang legal yang dapat meningkatkan performa lingkungan mereka dengan mengimplementasikan pembalakan berdampak rendah ataupun pengelolaan hutan secara lestari. Dapat juga sebagai pemegang konsesi atas perkebunan kelapa sawit yang dapat menyisihkan sebagian dari daerah konsesi mereka untuk melindungi hutan dengan nilai konservasi yang tinggi, ataupun pemangku kepentingan setempat yang dapat mengurangi kegiatan pembukaan hutan dengan terlibat dalam pengelolaan hutan lestari berskala kecil ataupun praktik-praktik perluasan wanatani.

3. Kemitraan dengan pemerintah. Pemrakarsa dapat menandatangani kesepakatan dengan Pemerintah Indonesia untuk mengembangkan kegiatan percontohan REDD+ dan membagi kredit karbon yang dihasilkan dari intervensi kegiatan percontohan tersebut. Serupa dengan model kemitraan yang lain, pemrakarsa proyek tidak memiliki hak legal untuk memiliki wilayah ataupun karbon, namun ikut ambil bagian dalam kontrak kesepakatan untuk mengembangkan kegiatan percontohan sehingga sebagai gantinya dapat memperoleh bagian dari keuntungan karbon. Sebagai contoh, seorang pemrakarsa dapat bermitra dengan pemerintah daerah untuk meningkatkan pengelolaan pada kawasan hutan lindung.

4. Tanpa hak karbon. Dalam kasus ini, 'pemrakarsa' benar-benar mendukung pemerintah untuk menerapkan berbagai kegiatan REDD+ dan Pemerintah Indonesia (pada tingkat nasional, provinsi maupun kabupaten) yang akan memegang semua hak terkait. Walaupun organisasi pemrakarsa eksternal secara aktif mengembangkan kegiatan percontohan REDD+ dan kemungkinan tidak ada intervensi REDD+ tanpa pemrakarsa eksternal, pembagian hak karbon bukanlah tujuannya.

\section{Pemicu dan agen utama dalam deforestasi dan degradasi}

Kegiatan percontohan REDD+ pada contoh studi ini menindaklanjuti dua kelompok pemicu dan agen, yaitu: deforestasi dan degradasi terencana oleh agen berskala industri, dan deforestasi dan degradasi tidak terencana oleh para petani kecil. Menurut VCS, deforestasi dan degradasi terencana ditetapkan atau disetujui oleh pemerintah dan termasuk di dalam dokumen pengelolaan lahan atau perencanaan tata ruang (VCS 2008c). Di Indonesia, hal ini dapat dilakukan dalam beberapa bentuk, termasuk konversi hutan menjadi produksi komoditas berskala industri, seperti halnya minyak kelapa sawit, karet dan bubur kayu, serta kepentingan pertambangan. Deforestasi dan degradasi 'tidak terencana' merupakan hal yang tidak didukung, yang diakibatkan oleh ketidakmampuan institusi untuk mengendalikan pemanfaatan hutan, dan termasuk di dalamnya perambahan areal hutan yang ditujukan untuk perlindungan, untuk pembalakan kayu maupun bentuk penggunaan lain (VCS 2008c). Termasuk di dalam deforestasi dan degradasi yang tidak terencana adalah kehilangan hutan yang disebabkan oleh berbagai kegiatan yang tidak sah secara hukum. Deforestasi 
yang terencana maupun yang tidak terencana dapat ditimbulkan oleh petani kecil maupun agen-agen berskala industri: sebuah contoh deforestasi yang tidak terencana oleh agen berskala industri adalah perluasan perkebunan tanpa pengesahan/persetujuan; sementara itu program transmigrasi merupakan contoh deforestasi terencana yang dilakukan oleh petani kecil yang disetujui oleh negara. Pada praktiknya, semua kegiatan percontohan REDD+ tingkat lokal pada contoh kami memilih untuk berfokus pada deforestasi terencana oleh agribisnis besar dan perusahaan kayu ataupun deforestasi tidak terencana oleh pertanian rumah tangga, operasi pembalakan setempat dan para pelaku berskala kecil lainnya. Adapun seluruh kegiatan percontohan pada tingkat bentang alam menindaklanjuti keduanya, dan beberapa kegiatan juga menindaklanjuti deforestasi tidak terencana berskala industri dan deforestasi terencana oleh petani kecil melalui proses perencanaan tata ruang.

Kombinasi dari tiga dimensi tersebut dapat mengidentifikasikan tipe-tipe kegiatan percontohan REDD+ di antara 17 contoh yang ada (Tabel 1).

Sebelumnya mungkin diharapkan bahwa tipe organisasi yang mendanai kegiatan percontohan (misalnya LSM lingkungan hidup, agen donor bilateral dan investor sektor swasta) akan terkait dengan keputusan struktural awal, namun kami tidak mendeteksi adanya pola yang konsisten (hasil dapat diperoleh dari penulis utama). Hal ini kemungkinan terjadi karena adanya koalisi besar dan berpindah dari organisasi yang terlibat dalam kegiatan percontohan ini, yang menyebabkan sulitnya membedakan pola-pola tersebut pada fase awal pengembangannya.

\section{Sejumlah motivasi untuk berbagai tipe kegiatan percontohan REDD+}

Kegiatan percontohan REDD+ tidak terdistribusi secara merata pada semua tipe yang ada (Tabel 1). Dengan menyadari bahwa jumlah dan tipe kegiatan percontohan terus berkembang dengan cepat, kami yakin bahwa contoh yang kami gunakan menunjukkan kecenderungan awal yang informatif. Pada bagian ini, kami mengajukan beberapa kemungkinan penjelasan/ alasan untuk kecenderungan ini.

\section{Kegiatan percontohan tingkat bentang alam yang 'dimiliki' oleh Pemerintah Indonesia dapat beradaptasi terhadap situasi peraturan yang terus berubah}

Kegiatan percontohan pada tingkat bentang alam memiliki setidaknya tiga keuntungan penting: kegiatankegiatan tersebut mencakup wilayah besar dengan cadangan karbon yang besar sehingga memiliki potensi untuk memberikan dampak yang besar bagi emisi; kegiatan-kegiatan ini memiliki jalan yang jelas untuk mengintegrasikan berbagai kebijakan REDD+ di masa mendatang dan sejumlah rencana pengembangan rencana rendah karbon; kegiatan-kegiatan ini menginternalisasi dan oleh karena itu kemungkinan akan lebih efektif dalam mengelola (bukan menghilangkan) kebocoran. Namun demikian, pada saat yang sama, proses pelaksanaan, implementasi dan pemantauannya juga merupakan hal yang rumit. Menurut definisi, para pemrakarsa kegiatan percontohan pada tingkat bentang alam yang bekerja sama dengan pemerintah, mengintegrasikan sejumlah prioritas dalam pemanfaatan lahan berkarbon rendah ke dalam proses perencanaan

Tabel 1. Klasifikasi kegiatan percontohan REDD+

\begin{tabular}{|c|c|c|c|c|}
\hline \multirow[t]{2}{*}{$\begin{array}{l}\text { Tingkat bentang alam } \\
\text { atau lokal }\end{array}$} & \multirow[t]{2}{*}{$\begin{array}{l}\text { Strategi untuk menetapkan } \\
\text { hak legal atas karbon }\end{array}$} & \multicolumn{2}{|c|}{$\begin{array}{l}\text { Pemicu dan agen utama dari deforestasi } \\
\text { dan degradasi }\end{array}$} & \multirow[t]{2}{*}{ Total } \\
\hline & & $\begin{array}{l}\text { Direncanakan oleh aktor } \\
\text { berskala industri }\end{array}$ & $\begin{array}{l}\text { Tidak direncanakan } \\
\text { oleh petani kecil }\end{array}$ & \\
\hline \multirow[t]{2}{*}{ Bentang alam } & Kemitraan dengan pemerintah & \multicolumn{2}{|c|}{ Keduanya } & 2 \\
\hline & Tanpa hak karbon & \multicolumn{2}{|c|}{ Keduanya } & 3 \\
\hline Subtotal tingkat bentang alam & & & & 5 \\
\hline \multirow[t]{4}{*}{ Tingkat lokal } & Model konsesi & 8 & 0 & 8 \\
\hline & $\begin{array}{l}\text { Kemitraan dengan pemakai } \\
\text { lahan }\end{array}$ & 2 & 0 & 2 \\
\hline & Kemitraan dengan pemerintah & 0 & 1 & 1 \\
\hline & Tanpa hak karbon & 0 & 1 & 1 \\
\hline Subtotal tingkat lokal & & 10 & 2 & 12 \\
\hline Total & & & & 17 \\
\hline
\end{tabular}


tata ruang pada daerah yang besar. Oleh karena itu, secara logis mereka juga mencakup deforestasi yang terencana maupun tidak terencana. Tiga dari lima kegiatan percontohan pada tingkat bentang alam tidak mengklaim hak karbon dalam bentuk apa pun. Mereka didanai oleh organisasi donor internasional ataupun LSM (terkait konservasi) yang besar yang bermitra dengan berbagai tingkat dalam Pemerintah Indonesia untuk mengembangkan sejumlah kegiatan percontohan yang resmi. Sebuah kelebihan utama dari pendekatan ini adalah kemampuannya untuk beradaptasi terhadap peraturan yang terus berubah.

\section{Biaya transaksi dan risiko reputasi merupakan faktor penting yang membentuk struktur kegiatan percontohan pada tingkat lokal. Secara relatif, hanya} terdapat sedikit pemrakarsa yang bermitra dengan pengguna lahan ataupun pemerintah untuk kegiatan percontohan tingkat lokal, yang kemungkinan besar disebabkan oleh tingginya biaya transaksi. Dari ketiga kegiatan percontohan yang mengusung strategi kemitraan, satu bermitra dengan konsesi minyak kelapa sawit, satu dengan konsesi kayu dan satu dengan pemerintahan daerah yang memiliki otoritas untuk melindungi hutan. Hasil wawancara menunjukkan bahwa adanya biaya transaksi telah menurunkan motivasi dari kegiatan percontohan untuk menerapkan model kemitraan. Dikemukakan bahwa sejumlah faktor penghambat untuk pendekatan ini adalah adanya hambatan birokrasi untuk bekerja sama dengan pemerintah dan hambatan logistik untuk bekerja sama dengan sejumlah besar petani kecil. Para pemrakarsa lebih secara aktif bermitra dengan para pelaku berskala industri, yang lebih tidak birokratis dan jumlahnya tidak terlalu banyak. Kenyataannya, sejumlah pemrakarsa telah berusaha untuk mengembangkan kegiatan percontohan berbasis kemitraan dengan pemakai lahan berskala industri, namun kesulitan untuk mencapai kesepakatan bersama dan menjawab sejumlah kekhawatiran terkait risiko reputasional dari kerja samanya dengan perusahaan agribisnis ataupun kayu yang kemungkinan telah memperoleh konsesi tersebut secara tidak sah dan/atau secara tidak adil bernegosiasi (atau tidak bernegosiasi sama sekali) dengan para petani kecil.

Sampai sejauh ini, pendekatan yang paling umum digunakan untuk menetapkan klaim karbon jangka panjang adalah usaha untuk memperoleh konsesi. Pada tujuh dari delapan kegiatan percontohan yang mengadopsi pendekatan ini, pemrakarsa menggunakan sebuah ERC (atau yang setara dengan provinsi). Proses dalam memperoleh ERC melibatkan pemerintah kabupaten, provinsi maupun pusat, serta sejumlah tingkat pembuat keputusan yang berbeda. Oleh karena itu, biaya transaksi untuk pendekatan ini juga cukup besar - kenyataannya, banyak dari kegiatan percontohan yang belum memperoleh persetujuan akhir atas ERC mereka sampai dengan September 2010. Namun demikian, strategi ini cukup populer, karena walaupun biaya transaksi awalnya besar, kegiatan percontohan dengan model konsesi tidak akan menghadapi biaya transaksi berjalan yang berkaitan dengan negosiasi kemitraan.

Dari sejumlah contoh kegiatan percontohan yang digunakan pada studi ini, tidak satupun yang berencana untuk menetapkan klaim karbon mereka melalui kemitraan dengan petani kecil. Hasil wawancara mengindikasikan bahwa tingginya biaya transaksi untuk bernegosiasi dengan sejumlah besar pelaku telah menurunkan motivasi untuk mengadopsi model tersebut.

Kepastian tenurial jangka panjang merupakan hal yang sangat penting untuk validasi dan pengembalian biaya. Kepastian tentang kelangsungan hidup dari sebuah kegiatan percontohan (atau permanensi dari klaim karbon) juga merupakan faktor penting yang menjadi penentu dalam model konsesi. Sebagian besar pemrakarsa berkepentingan untuk memastikan bahwa kegiatan percontohan yang mereka lakukan akan berlangsung cukup lama untuk mengembalikan biaya awal yang besar. Sementara untuk memperoleh validasi dari VCS, pemrakarsa harus dapat secara tepat menindaklanjuti risiko nonpermanensi, termasuk risiko adanya ketidakjelasan dan potensi konflik tenurial (VCS 2008b). Lebih jauh lagi, kepastian tenurial merupakan hal yang paling penting untuk investor Indonesia maupun investor asing. Sebuah ERC akan memungkinkan pemrakarsa untuk melakukan klaim dengan tingkat kepastian yang kuat bahwa mereka memiliki kepastian tenurial untuk 60 tahun, dapat diperbarui untuk 35 tahun kemudian (dengan asumsi bahwa mereka memenuhi peraturan yang relevan); serupa dengan itu, konsesi kayu dan perkebunan juga memungkinkan pemrakarsa untuk melakukan klaim bahwa kegiatan percontohan mereka akan berlanjut untuk jangka waktu yang sudah diketahui. Oleh karena itu, dibandingkan dengan alternatif model kemitraan untuk menetapkan klaim atas karbon, model konsesi nampaknya akan menjadi solusi yang terbaik untuk menetapkan klaim karbon berjangka panjang yang pasti. Pada praktiknya, para pemrakarsa proyek menghadapi klaim yang saling bersaing atas lahan yang sama oleh pemangku kepentingan yang berbeda (terkadang diakui oleh tingkatan pemerintah yang berbeda), yang memperumit dan memperpanjang proses aplikasi konsesi tersebut. Ketika pemrakarsa proyek yang mengadopsi model konsesi telah memiliki klaim atas lahan yang telah diakui secara hukum (dan oleh karena itu merupakan klaim secara tidak langsung terhadap karbon, bergantung pada persyaratan perizinan), terdapat sedikit kepastian dalam model kemitraan di mana pemrakarsa proyek memegang kendali dari kegiatan percontohan, dan 
sang mitra (pemegang konsesi atau pemerintah daerah) sendiri yang memiliki hak atas lahan. Walaupun karbon merupakan prioritas utama dari pemrakarsa proyek, mitra mereka haruslah menyeimbangkan sejumlah prioritas yang lain, termasuk produksi minyak kelapa sawit, volume kayu dan kepentingan para pemilih. Apabila sejumlah prioritas ini mengalami konflik di masa mendatang, mitra mereka dapat mengusahakan untuk menegosiasikan ulang kesepakatan, meningkatkan biaya transaksi dan mengancam klaim karbon dari pemrakarsa proyek.

Tata kawasan tenurial dan sistem klasifikasi hutan yang ada saat ini membentuk pemerataan sejumlah tipe kegiatan percontohan. ERC hanya dapat diterapkan pada hutan produksi dan hutan produksi konversi, dan saat ini tidak terdapat mekanisme setara yang dapat digunakan oleh pemrakarsa proyek untuk mengembangkan kegiatan percontohan REDD+ pada tipe hutan lain atau daerah tidak berhutan lainnya. Oleh karena itu, apabila model konsesi tetap menjadi pilihan paling menarik bagi para pemrakarsa untuk menetapkan klaim karbon berjangka panjang, maka Indonesia dapat melihat bahwa kebanyakan kegiatan percontohan REDD+ dikembangkan pada hutan produksi walaupun emisi juga bersumber dari semua tipe hutan dan berbagai kelompok pelaku.

Berdasarkan sejarah, tata kawasan tenurial di Indonesia telah lama berpihak pada sejumlah perusahaan berskala besar dan terdapat sistem konsesi hutan yang terbentuk dengan baik dan telah teruji (Agrawal dkk. 2008). Model konsesi ini sejalan dengan sistem tenurial yang ada saat ini dan oleh karena itu memberikan cukup kepastian yang memungkinkan kegiatan percontohan REDD+ untuk melangkah lebih daripada program nasional. Namun demikian, mengingat model konsesi telah disesuaikan dengan sistem tenurial dan tata kelola yang ada saat ini, nampaknya implementasi dari kegiatan percontohan REDD+ yang menggunakan model ini tidak akan efektif menjawab adanya ketidaksetaraan dan kekurangan lain dari sistem yang berlaku.

Di Indonesia, hak milik lahan petani kecil sering kali tidak diakui. Sebagai akibatnya, bahkan jika sebuah kegiatan percontohan sanggup menutupi biaya transaksi kerja sama dengan sejumlah petani kecil, kegiatan tersebut kemungkinan tidak akan dapat menunjukkan mata rantai wilayah dan karbon yang dituntut oleh investor dan untuk validasi menurut standar-standar utama. REDD+ seringkali dipahami sebagai sebuah bentuk pembayaran atas jasa lingkungan (PES): sukarela, transfer bersyarat dari penerima keuntungan ke penyedia jasa lingkungan (Sills dkk. 2009). Tidak adanya pengakuan atas hak para petani kecil dan masyarakat pribumi telah memperlambat perkembangan skema PES di wilayah Asia Tenggara (Wertz-Kanounnikoff dan KongphanApirak 2008) dan juga merupakan hambatan untuk pengembangan kegiatan percontohan REDD+ di Indonesia yang mendasarkan klaim mereka pada tambahan emisi permanen yang dihindari pada sejumlah kesepakatan dan program (seperti halnya PES) yang berfokus pada para petani kecil.

Persyaratan penambahan (additionality) kemungkinan telah menyebabkan tidak adanya kegiatan percontohan yang berfokus pada deforestasi dan degradasi yang tidak terencana oleh pelaku berskala industri. Validasi menurut VCS mensyaratkan agar kegiatan percontohan dapat menunjukkan adanya 'penambahan', yang mengandung arti bahwa pengurangan emisi merupakan tambahan bagi apa yang akan terjadi apabila tidak terdapat intervensi. Secara spesifik, pada salah satu kriterianya, VCS mensyaratkan bahwa intervensi tersebut 'tidak diharuskan oleh hukum, undang-undang, ataupun kerangka kerja pengaturan apa pun yang berlaku' (VCS 2008a). Tidak terdapat satupun kegiatan percontohan pada tingkat lokal yang memfokuskan diri untuk menghentikan deforestasi dan degradasi tidak terencana yang dilakukan oleh para pelaku berskala industri, meskipun ini merupakan sebuah pemicu emisi, misalnya, melalui ekspansi perkebunan tanpa persetujuan yang dilakukan pada daerah hutan yang berbatasan. Tidak adanya kegiatan percontohan tipe ini kemungkinan disebabkan sulitnya membuktikan penambahan, di luar apa yang secara teknis telah disyaratkan dan dimungkinkan untuk dilakukan menurut hukum di Indonesia. Kegiatan percontohan yang membidik sejumlah kegiatan tidak terencana oleh petani kecil kemungkinan akan lebih mampu untuk menjawab penambahan dengan cara menunjukkan bahwa sejumlah kegiatan ini secara relatif lebih sulit untuk dipantau dan diatur.

\section{Kebutuhan penelitian di masa mendatang dan implikasinya untuk rancangan REDD+ di Indonesia}

Dengan menggunakan tiga dimensi utama pada struktur awal kegiatan percontohan REDD+, kami telah mengidentifikasi enam tipe kegiatan percontohan di Indonesia. Penelitian yang terus memantau performa dari sejumlah tipe kegiatan percontohan dan menganalisa kemampuan mereka agar efisien, efektif dan berkesetaraan, menghasilkan pengurangan emisi berikut manfaat tambahan lingkungan dan sosial akan dapat menginformasikan tipe kegiatan percontohan 
mana yang perlu untuk ditingkatkan dan direplikasi pada situasi tertentu.

Tipe paling umum dari kegiatan percontohan adalah model konsesi untuk menghindari deforestasi terencana oleh agen berskala industri. Hal ini sejalan dengan menonjolnya pertanian dan perkebunan intensif sebagai pemicu utama deforestasi dan degradasi di Indonesia (Butler dan Laurance 2008). Namun demikian, model konsesi hanya dapat diterapkan pada hutan produksi dan hutan produksi konversi. Agar kegiatan percontohan REDD+ dapat membidik pemicu berskala industri pada tipe hutan yang lain, strategi yang baru atau dimodifikasi haruslah dikembangkan untuk tipe hutan yang lain dan pada wilayah yang berada di luar kawasan hutan yang telah ditetapkan secara hukum.

Pertanian berskala kecil dan tradisional juga merupakan pemicu penting dari deforestasi dan degradasi, namun tindak lanjut yang dilakukan kegiatan percontohan tingkat lokal terhadap pemicu ini masih sangat terbatas. Agar kegiatan percontohan REDD+ dapat menindaklanjuti deforestasi yang terkait pertanian berskala kecil dan tradisional, sejumlah langkah perlu dilakukan untuk mengurangi biaya transaksi dan untuk mengatasi kesulitan dalam pemantauan, pelaksanaan dan validasi metodologi.

Biaya transaksi menghambat perkembangan kegiatan percontohan yang bermitra dengan petani kecil dalam mengurangi emisi. Pemerintah Indonesia, serta sejumlah LSM dan organisasi donor dapat mengembangkan suatu model dan strategi untuk mengurangi biaya transaksi, kemungkinan dengan menyatukan sejumlah petani kecil dan mengelompokkan sejumlah proyek mereka. Dengan demikian akan meningkatkan efisiensi biaya dan mendorong perkembangan tipe baru atau tipe modifikasi dari kegiatan percontohan yang dapat secara langsung lebih melibatkan petani kecil.

Model kegiatan percontohan REDD+ setelah skema PES, dimana petani kecil menyediakan jasa pengurangan emisi, memiliki potensi untuk membantu pengentasan kemiskinan bagi komunitas yang berpartisipasi (Peskett dkk. 2008; Wunder dkk. 2008). Skema ini mensyaratkan bahwa petani kecil memegang kendali atas sumber daya mereka; namun pada kenyataannya hak petani kecil ini sering kali tidak diakui di Indonesia. Sebagai hasilnya, kegiatan percontohan yang bertujuan untuk bekerja sama dengan petani kecil sebagai penyedia jasa menemui kesulitan untuk dapat menjalankan tenurial jangka panjang yang disyaratkan untuk memperoleh validasi dan menarik investor. Sebaliknya, sejumlah pelaku berskala industri seringkali memiliki hak yang diakui secara resmi atas hutan dalam bentuk konsesi yang dikeluarkan oleh Pemerintah Indonesia. Oleh karena itu lebih mudah untuk menganggap dan mengkompensasi pelaku berskala industri sebagai penyedia jasa. Berbagai LSM dan organisasi donor dapat membantu Pemerintah Indonesia untuk mewujudkan lingkungan yang kondusif bagi kegiatan percontohan REDD+ yang menyediakan PES bagi para petani kecil dengan meningkatkan kepastian jangka panjang atas hak petani kecil.

Cadangan karbon hanya merupakan salah satu manfaat yang diharapkan dari REDD+. Draf teks mengenai REDD+ yang dikembangkan oleh Ad Hoc Working Group of Long-term Cooperative Actions (AWG-LCA) di bawah UNFCCC, secara khusus menyatakan bahwa berbagai kegiatan REDD+ haruslah berkontribusi bagi pembangunan berkelanjutan dan pengurangan kemiskinan (UNFCCC 2009). Sebanyak tiga belas dari 17 kegiatan percontohan dalam penelitian ini menerapkan akreditasi oleh standar Community and Biodiversity Alliance (CCBA) yang mensyaratkan bahwa kegiatan percontohan harus memiliki dampak nilai positif terhadap masyarakat (CCBA 2008). Semua pemrakarsa proyek yang telah diwawancarai menyatakan bahwa meningkatkan penghidupan setempat merupakan prioritas. Banyak dari mereka juga menekankan bahwa investasi atas penghidupan merupakan hal yang sangat penting untuk keberlanjutan jangka panjang dari kegiatan percontohan mereka. Beberapa proyek yang diusulkan telah berusaha untuk menghantarkan manfaat konkret bagi petani kecil dengan memberdayakan mereka dalam pelaksanaan atau dalam berbagai kegiatan untuk merestorasi hutan dan lahan gambut yang terdegradasi. Namun demikian, sangat sedikit kegiatan percontohan yang telah memulai implementasi, dan banyak juga yang masih memiliki daftar kegiatan implementasi yang mungkin dilakukan, yang akan sesuai dengan struktur awal mereka yang telah terbentuk. Kebanyakan dari elemen yang paling berpengaruh dalam pengentasan kemiskinan belum ditetapkan dalam struktur inti untuk mengurangi emisi karbon. Oleh karena itu keluaran aktual terkait masalah ini belum diketahui dan kemungkinan akan dipengaruhi oleh pengelolaan di masa mendatang dan keputusan implementasi tanpa dipengaruhi oleh tipe proyek sebagaimana yang didefinisikan di sini. Penelitian di masa mendatang haruslah menganalisis apakah beberapa tipe proyek tertentu akan lebih sukses dalam mencapai tujuan pengentasan kemiskinan.

Berbagai kegiatan percontohan dalam penelitian ini telah mengembangkan sejumlah strategi REDD+ dalam batasan tata kawasan tenurial yang berlaku saat ini. 
Sebagai akibatnya, kemungkinan mereka tidak berada dalam posisi yang menguntungkan untuk memelopori pemecahan masalah terkait ketidaksetaraan yang terdapat pada tata kawasan tersebut. Jelas terdapat risiko bahwa keterbatasan dari sistem tenurial yang ada saat ini dapat terulang pada sistem REDD+ di masa mendatang. Untuk menindaklanjuti hal tersebut dibutuhkan reformasi kebijakan yang luas melebihi cakupan masingmasing kegiatan percontohan REDD+, sebagai contoh, dalam hal peraturan dan persyaratan untuk pembagian manfaat setempat dan pengelolaan bersama atas konsesi. Pada masa sebelumnya, berbagai usaha untuk reformasi kebijakan semacam itu belum sepenuhnya berhasil, namun REDD+ menciptakan peluang dan kondisi yang mendesak untuk mencoba kembali usaha

tersebut. Sejumlah program nasional sebaiknya diposisikan untuk menindaklanjuti ketidaksetaraan dan ketidakefisienan dalam tata kawasan tenurial yang ada saat ini. Hal ini akan dibutuhkan sebagai tambahan dari kegiatan-kegiatan percontohan, baik untuk mendorong berkembangnya tipe kegiatan percontohan maupun untuk mereformasi model konsesi dasar yang ada di Indonesia.

Tiga dari lima kegiatan percontohan pada tingkat bentang alam tidak menetapkan klaim atas hak karbon untuk mereka sendiri. Mereka dimotori oleh organisasi bantuan bilateral ataupun LSM internasional besar yang bermitra dengan berbagai tingkatan pemerintah Indonesia untuk mengembangkan sejumlah kegiatan percontohan yang resmi. Keuntungan dari pendekatan ini adalah sangat adaptif terhadap situasi peraturan yang terus berubah. Apabila Pemerintah Indonesia mengembangkan sebuah program nasional REDD+ yang kuat, maka kegiatan percontohan tingkat bentang alam di mana pemrakarsa proyek tidak menetapkan klaim atas hak karbon kemungkinan akan lebih mampu untuk beradaptasi terhadap perkembangan kerangka kerja peraturan REDD+. Ini dikarenakan mereka 'dimiliki' oleh Pemerintah Indonesia dan terintegrasi ke dalam proses perencanaan tata ruang. Dengan mengintegrasikan kegiatan percontohan tingkat bentang alam ke dalam rencana tata ruang dan strategi pembangunan ekonomi, seperti halnya rencana pengembangan berkarbon rendah yang sedang dikembangkan pada sedikitnya tiga provinsi, REDD+ dapat menjadi bagian dari alur pembangunan jangka panjang.

\section{Kesimpulan}

Info singkat ini menyajikan sebuah gambaran atas persepsi pemrakarsa dan berbagai tipe kegiatan percontohan REDD+ yang bermunculan di Indonesia pada tahun 2009. CIFOR terus melanjutkan penelitian dengan suatu ukuran contoh yang lebih kecil dari kegiatan percontohan generasi pertama ini, sebagai bagian dari Studi Komparatif Global atas REDD+. Klasifikasi yang diusulkan di sini membantu menginformasikan penelitian tersebut yang mengambil langkah lanjutan penting dalam penilaian yang ketat mengenai dampak kegiatan percontohan terhadap penghidupan dan pemanfaatan lahan setempat.

Kegiatan percontohan REDD+ di Indonesia saat ini, merupakan tindak lanjut dari tujuan yang diharapkan dari Bali Road Map. Ini menunjukkan bahwa program nasional REDD+ dapat diterapkan pada tingkat daerah, dan juga menggambarkan tantangan dan perlunya reformasi sistem kelembagaan, peraturan dan tenurial yang berlaku. Di Indonesia, kerangka kerja peraturan dan kelembagaan untuk REDD+ saat ini mengalami perkembangan pesat. Hal ini menunjukkan besarnya peluang untuk menggabungkan sejumlah pembelajaran yang diperoleh dari berbagai kegiatan percontohan. Berbagai pengalaman kegiatan percontohan REDD+ di Indonesia menawarkan sejumlah pembelajaran global tentang beberapa jalan alternatif untuk membentuk kegiatan subnasional, bagaimana berbagai alternatif tersebut dibentuk oleh kondisi kelembagaan dan tata kelola, dan - melihat ke depan - pada dampak serta keluaran dari berbagai tipe kegiatan percontohan REDD+ yang berbeda.

\section{Catatan}

1. Pada diskusi kebijakan global tentang REDD+, istilah kegiatan percontohan (pilot) memiliki banyak definisi dan implikasi yang berbeda. Dalam info singkat ini, kami menggunakan 'kegiatan percontohan' yang berlawanan dengan sebuah proyek. Suatu proyek dapat memiliki satu atau lebih kegiatan percontohan, umumnya pada provinsi yang sama, yang dikumpulkan menjadi satu kesatuan untuk usaha pencarian dana dan tujuan yang lain. Sejumlah kegiatan percontohan yang membentuk sebuah proyek, masing-masing memiliki strategi yang berbeda.

\section{Kami menggunakan kriteria 'memiliki suatu} kesepakatan resmi dengan beberapa tingkatan pemerintah' sebagai indikator bahwa kegiatan percontohan tersebut telah melewati fase konsep dan telah membuat beberapa keputusan kunci awal tentang strukturnya. Mengingat kami menggunakan kriteria ini sebagai pengganti untuk tahap pengembangan dari kegiatan percontohan serta rumitnya konteks peraturan untuk REDD+ yang tidak memiliki penetapan yang jelas tentang tingkat pemerintahan yang mana yang harus atau dapat memberikan persetujuan atas berbagai 
kegiatan subnasional, maka kami beranggapan bahwa kesepakatan dengan tingkat apa pun dalam pemerintah atau kementerian dalam Pemerintah Indonesia sudah memenuhi syarat bagi sebuah kegiatan percontohan untuk dijadikan sebagai unit contoh kami.

3. Kami melaksanakan wawancara semiterstruktur dengan semua pemrakarsa proyek kecuali satu proyek. Pada perkecualian ini, pemrakarsa proyek tidak hadir namun menyediakan semua dokumen proyek dan merespon pertanyaan yang disampaikan melalui surat elektronik. Perlu diperhatikan bahwa beberapa pemrakarsa proyek mengimplementasikan lebih dari satu kegiatan percontohan.

\section{Daftar pustaka}

Agrawal, A., Chhatre, A. dan Hardin, R. 2008 Changing governance of world's forests. Science 320: 1460-1462.

Atmadja, S. dan Wollenberg, E. 2010 Indonesia. Dalam: Springate-Baginski, O. dan Wollenberg, E. (ed.) REDD, forest governance and rural livelihoods: the emerging agenda, 73-94. CIFOR, Bogor, Indonesia.

Barr, C., Resosudarmo, I.A.P., Dermawan, A., McCarthy, J., Moeliono, M. dan Setiono, B., (ed.) 2006 Decentralization of forest administration in Indonesia: implications for forest sustainability, economic development and community livelihoods. CIFOR, Bogor, Indonesia.

Boer, R., Sulistyowati, Las, I., Zed, F., Masripatin, N., Kartakusuma, D.A., Hilman, D. dan Mulyanto, H.S. 2010 Summary for policy makers: Indonesia second national communication under the United Nations Framework Convention on Climate Change (UNFCCC) (rev. 16 Januari 2010). Kementerian Lingkungan Hidup, Pemerintah Indonesia, Jakarta, Indonesia.

Butler, R.A. dan Laurance, W.F. 2008 New strategies for conserving tropical forests. Trends in Ecology and Evolution 23 (9): 469-472.

Climate, Community and Biodiversity Alliance, The (CCBA) 2008 Climate, community and biodiversity project design standards. Edisi kedua. CCBA, Arlington, VA, AS.

Center for International Forestry Research (CIFOR) 2010 REDD+ project sites in Indonesia. Tersedia di http:// www.forestsclimatechange.org/index.php?id=292 (20 Oktober 2010).

Ecosecurities 2010 The forest carbon offsetting report 2010. EcoSecurities, Dublin, Republik Irlandia. Tersedia di: http://www.ecosecurities.com/Registered/ ForestCarbonOffsettingReport2010.pdf (20 Oktober 2010).
Government of Indonesia 2010 National strategy REDD: Indonesia readiness phase 2009-2012 and progress in implementation. Kementerian Kehutanan, Jakarta, Indonesia. Tersedia di http://www.forda-mof.org/ uploads/2010/buku\%20redd\%20versi\%20english.pdf (20 Oktober 2010).

Gray, J. 2002 Forest concession policies and revenue systems: country experience and policy changes for sustainable tropical forestry. World Bank Technical Paper, Forest Series, Washington, DC.

Hinrichs, A., Muhtaman, D.R. dan Irianto, N. 2008 Forest certification on community land in Indonesia. Gesellschaft für Internationale Zusammenarbeit, Jakarta, Indonesia.

Peskett, L., Huberman, D., Bowen-Jones, E., Edwards, G. dan Brown, J. 2008 Making REDD work for the poor. A Poverty Environment Partnership (PEP) report. Tersedia di http://cmsdata.iucn.org/downloads/ making_redd_work_for_the_poor_final_draft_0110. pdf (20 Oktober 2010).

Resosudarmo, I.A.P. 2004 Closer to people and trees: will decentralisation work for the people and the forests of Indonesia? European Journal of Development Research 16 (1): 110-132.

Sills, E., Madeira, E., Sunderlin, W. dan Wertz-Kanounnikoff, S. 2009 The evolving landscape of REDD+ projects. Dalam: Angelsen dkk. (ed.) Realising REDD+: national strategy and policy options, 265-280. CIFOR, Bogor, Indonesia.

Sunderlin, W.D., Hatcher, J. dan Liddle, M. 2008 From exclusion to ownership? challenges and opportunities in advancing forest tenure reform. Rights and Resources Group, Washington, DC.

United Nations Framework Convention on Climate Change (UNFCCC) 2009 Outcome of the work of the Ad Hoc Working Group on Long-term Cooperative Action under the Convention; Draft decision -/CP.15; Policy approaches and positive incentives on issues relating to reducing emissions from deforestation and forest degradation in developing countries; and the role of conservation, sustainable management of forests and enhancement of forest carbon stocks in developing countries. FCCC/AWGLCA/2009/L.7/ Add.6, 15 Desember 2009. UNFCCC, Bonn, Jerman.

Voluntary Carbon Standard (VCS) 2008a Voluntary Carbon Standard program guidelines, 2007.1. VCS, Washington, DC.

Voluntary Carbon Standard (VCS) 2008b Voluntary Carbon Standard: tool for AFOLU non-permanence risk analysis and buffer determination. VCS, Washington, DC.

Voluntary Carbon Standard (VCS) 2008c Voluntary Carbon Standard: guidance for agriculture, forestry and other land use projects. VCS, Washington, DC. 
Voluntary Carbon Standard (VCS) 2010 Voluntary Carbon Standard: VCS consultation document: proposal for inclusion of peatland rewetting and conservation (PRC) under the VCS Agriculture, Forestry and Other Land Use (AFOLU) Program. VCS, Washington, DC.

Wertz-Kanounnikoff, S. dan Kongphan-Apirak, M. 2008 Reducing forest emissions in Southeast Asia: a review of drivers of land-use change and how payments for environmental services (PES) schemes can affect them. Working Paper No. 41. CIFOR, Bogor, Indonesia.

Wertz-Kanounnikoff, S. dan Kongphan-Apirak, M. 2009 Emerging REDD+: a preliminary survey of demonstration and readiness activities. Working Paper No. 46. CIFOR, Bogor, Indonesia.

Wunder, S., Engel, S. dan Pagiola, S. 2008 Taking stock: a comparative analysis of payments for environmental services programs in developed and developing countries. Ecological Economics 65 (4): 834-852.

\section{Ucapan terima kasih}

Penulis utama sangat berterima kasih kepada Fulbright Program dari Amerika Serikat, Kementerian Kehutanan Indonesia dan CIFOR untuk penyediaan dana, bantuan, bimbingan dan dukungannya. Dana penelitian juga diberikan melalui hibah kepada CIFOR oleh AusAID (Grant 46167). Kami berterima kasih kepada S. Atmadja, Y. Indriatmoko, L. Yuliani, M. Moelino, W. Sunderlin, K. Ginoga dan para pengembang proyek yang telah bersedia untuk diwawancarai serta kesediaannya untuk berbagi waktu dan keahlian mereka. Kami juga berterimakasih pada ketiga peninjau untuk sejumlah komentar dan saran yang sangat bermanfaat pada versi awal dari publikasi ini.

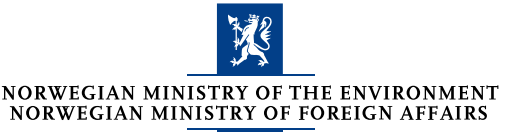

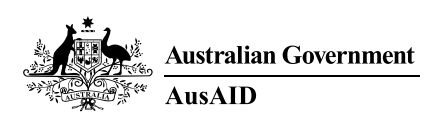

DFID

Department for

International Development

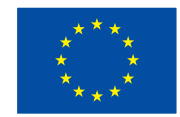

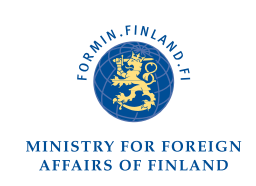

the David
Lucile Packard
Foundation
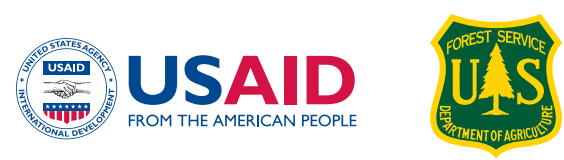